\title{
Value of Black Hills Forest Communities to Deer and Cattle
}

\section{JEREMIAH J. KRANZ AND RAYMOND L. LINDER}

Highlight: Aspen, pine, and mixed aspen-pine communities were studied at three different locations in the Black Hills National Forest of South Dakota from 1968 to 1970. Overstory densities were greatest in pine with a basal area (diameter at breast height) of $180.5 \mathrm{ft}^{2}$ per acre. Aspen-pine had $133.6 \mathrm{ft}^{2}$ per acre and aspen $89.5 \mathrm{ft}^{2}$ per acre. Understory production was inversely related to overstory density with 590 $\mathrm{lb} / \mathrm{acre}$ air-dried forage in aspen, $415 \mathrm{lb} / \mathrm{acre}$ in mixed aspenpine, and $215 \mathrm{lb} / \mathrm{acre}$ in pine. Aspen communities appeared to represent better feeding areas for both deer and cattle than mixed aspen-pine or pine. However, use by white-tailed deer, estimated by pellet group density, was greatest in mixed aspenpine. Cattle use, estimated by chip density, was greatest in aspen and least in pine.

Aspen (Populus tremuloides) is usually considered to be a subclimax species and is associated with a secondary seral stage in the western United States; rarely, it occurs as a climax species (Baker, 1918 and 1925). Stands of aspen normally develop on spruce-fir climax and on some pine sites following disturbance.

In recent years, some aspen stands in the Black Hills National Forest have been converted to ponderosa pine (Pinus ponderosa) to increase timber production. To determine the effect of this practice on white-tailed deer (Odocoileus virginianus) and cattle, the South Dakota Department of Game, Fish and Parks initiated a study in 1968 of deer and cattle use of aspen communities. Objectives of the study were to compare (1) overstories and understories of aspen, pine, and mixed aspen-pine, and (2) deer and cattle preference for these communities.

The authors are research biologist, Department of Game, Fish, and Parks, Rapid City, South Dakota; and leader, South Dakota Cooperative Wildlife Research Unit, South Dakota State University, Brookings.

The study was conducted under Federal Aid to Wildlife Restoration Project W-75-R in South Dakota. South Dakota Department of Game, Fish, and Parks, South Dakota State University, the U.S. Bureau of Sport Fisheries and Wildlife, and The Wildlife Management Institute cooperated in the research.

Manuscript received September 13, 1972.

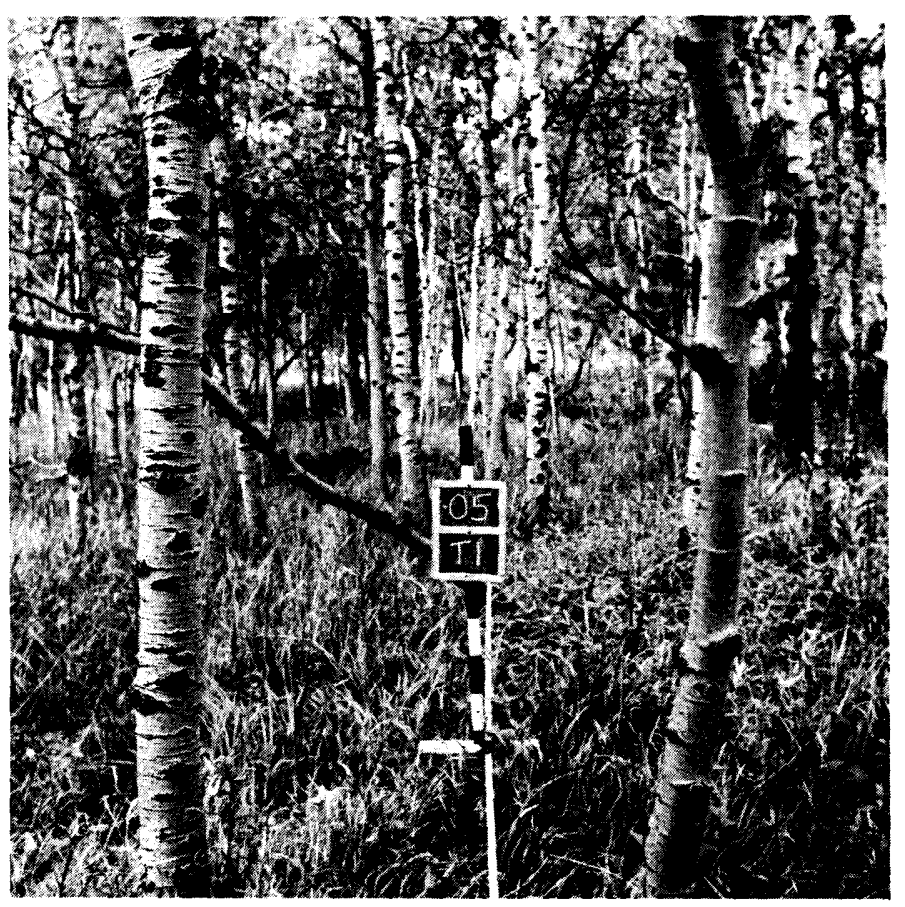

Fig. 1. Understory cover of most species was greater in aspen communities shown here than in aspen-pine or pine. Fifty-four species of shrubs and forbs were found in the aspen communities. (U.S. Forest Service photo by Kieth E. Severson)

\section{Study Area and Methods}

The Black Hills consist of an exposed crystalline core of igneous and metamorphic rock surrounded by eroded sedimentary formations of limestone and sandstone. Most of the soils are shallow, rocky, badlands soils modified by local conditions. Precipitation occurs chiefly during the growing season (April through September), and ranges from 17 inches per year in the south to 28 inches in the north (U.S. Dep. Agr. and U.S. Dep. of the Int., 1967).

Three areas (A, B and C) in the northern half of the Black Hills were studied from 1968 through 1970. Each area contained communities of aspen, pine, and mixed aspen-pine on gray wooded soils (Radeke and Westin, 1963). Soils of area A were of limestone origin with similar depths in the aspen, pine, and mixed aspen-pine. Soils of area B were also of limestone origin; however, soil depth was greatest in aspen and least in pine. Soils of area $\mathrm{C}$ resulted from breakdown of metamorphic rock and sandstones and were of similar depth.

Climax for all three study areas appeared to be ponderosa pine because all communities had various amounts of pine reproduction. Paper birch (Betula papyrifera), bur oak (Quercus macrocarpa), serviceberry (Amelanchier alnifolia), and white spruce (Picea glauca) also occurred.

Deer were present in the study areas for about 8 months each year; generally they were absent from December through March. Grazing by cattle was permitted from June 16 to September 20.

Criteria used to select study areas were: (1) that each contain one community of pure aspen, one of pine, and one consisting of a 50-50 mixture, and (2) the different communities be extensive enough to enable proper sampling without bias due to edge effect.

Nine belt transects $(1,000 \times 6 \mathrm{ft})$ were established, one in each community type in each study area, to measure overstory basal area, understory forage production, understory cover, and deer and cattle use.

Measurement of overstory basal area was made in 1970. A ten-factor wedge prism was used from the centerline of the nine belt transects, and square feet of basal area at diameter- 
Table 1. Basal area ( $\mathrm{dbh}^{1}$ in $\mathrm{ft}^{2} / \mathrm{acre}$ ) of overstory species for aspen, pine, and mixed aspen-pine communities in three study areas, Black Hills, 1970.

\begin{tabular}{clrrr}
\hline Area & Community & Aspen $^{2}$ & \multicolumn{1}{c}{ Pine $^{3}$} & Total \\
\hline A & Aspen & 95.9 & 3.3 & 99.2 \\
& Mixed & 32.2 & 122.0 & 154.2 \\
& Pine & 4.0 & 198.4 & 202.4 \\
B & Aspen & 73.4 & 25.2 & 98.6 \\
& Mixed & 25.4 & 124.4 & 149.8 \\
& Pine & 2.6 & 187.1 & 189.7 \\
C & Aspen & 61.4 & 10.0 & 71.4 \\
& Mixed & 30.5 & 66.3 & 96.8 \\
& Pine & 5.8 & 143.7 & 149.5 \\
Average & Aspen & 76.9 & 12.8 & 89.7 \\
& Mixed & 29.4 & 104.2 & 133.6 \\
& Pine & 4.1 & 176.4 & 180.5 \\
\hline
\end{tabular}

$1 \mathrm{dbh}=$ diameter-breast-height $(4.5 \mathrm{ft})$

2 Includes birch, bur oak, and serviceberry.

${ }^{3}$ Includes spruce.

Table 2. Percent cover of major species of vegetation which occurred in the understory of aspen, aspen-pine, and pine communities.

\begin{tabular}{|c|c|c|c|}
\hline Species & Aspen & $\begin{array}{c}\text { Aspen- } \\
\text { pine }\end{array}$ & Pine \\
\hline Grasses and sedges & 36.0 & 35.7 & 13.9 \\
\hline Clover (Trifolium repens) & 20.8 & 15.0 & 2.5 \\
\hline Filbert (Corylus cornuta) & 11.5 & 0.0 & 0.0 \\
\hline Oregon grape (Mahonia repens) & 11.8 & 12.2 & 10.1 \\
\hline Vetchling (Lathyrus ochroleucus) ${ }^{1}$ & 11.8 & 4.8 & 2.1 \\
\hline Aster (Aster sp.) ${ }^{1}$ & 10.7 & 4.3 & 1.1 \\
\hline Pasture brake (Pteridium aquilinum) & 8.2 & 4.2 & 0.2 \\
\hline Snowberry (Symphoricarpos sp.) & 6.2 & 8.2 & 3.3 \\
\hline Meadowrue (Thalictrum venulosum) & 4.8 & 1.0 & 0.2 \\
\hline Serviceberry (Amelanchier alnifolia) $)^{1}$ & 4.6 & 1.7 & 2.0 \\
\hline Bearberry (Arctostaphylo uva-ursi) & 4.3 & 13.8 & 15.4 \\
\hline Wild strawberry (Fragaria ovalis) & 3.3 & 2.2 & 0.8 \\
\hline Spirea (Spiraea lucida) & 3.1 & 6.4 & 6.1 \\
\hline Wild rose (Rosa sp.) & 2.8 & 2.1 & 1.5 \\
\hline Wild sarsaparilla (Aralia nudicaulis) & 2.6 & 0.2 & trace \\
\hline Lupine (Lupinus argenteus) & 2.4 & 1.4 & 0.4 \\
\hline Milk Vetch (Astragalus sp.) & 2.3 & 1.8 & 0.2 \\
\hline Hop hornbeam (Ostrya virginiana) & 2.0 & 0.0 & 0.0 \\
\hline American Vetch ${\text { (Vicia americana })^{1}}^{1}$ & 1.9 & 2.0 & 0.6 \\
\hline Yarrow (A chillea lanulosa) & 1.8 & 5.0 & 1.5 \\
\hline Wild bergamot (Monarda fistulo sa) & 2.9 & 3.2 & 0.6 \\
\hline Juniper (Juniperus sp.) & 0.0 & 1.3 & 3.0 \\
\hline Arnica (Arnica cordifolia) & 0.8 & 1.8 & 0.1 \\
\hline Others ${ }^{2}$ & 16.8 & 13.8 & 3.1 \\
\hline Total & 172.6 & 140.3 & 68.6 \\
\hline
\end{tabular}

${ }_{1}^{1}$ Four preferred food species in the northern Black Hills (Schneeweis, 1969).

${ }^{2}$ Includes 37 other species with less than $5 \%$ of total in all study areas.

Table 3. Shrub, forb, and grass production (lb/acre, air-dried) in aspen, mixed aspen-pine, and pine in three study areas, Black Hills, 1968-69.

\begin{tabular}{cllrrr}
\hline Area & Community & Shrub & Forb & Grass & Total \\
\hline \multirow{2}{*}{ A } & Aspen & 229 & 207 & 56 & 492 \\
& Mixed & 127 & 145 & 47 & 319 \\
& Pine & 146 & 18 & 12 & 176 \\
B & Aspen & 213 & 195 & 64 & 472 \\
& Mixed & 171 & 60 & 10 & 241 \\
& Pine & 128 & 38 & 20 & 186 \\
C & Aspen & 179 & 200 & 424 & 803 \\
& Mixed & 159 & 193 & 333 & 685 \\
& Pine & 189 & 67 & 139 & 395 \\
Average & Aspen & 207 & 201 & 181 & 589 \\
& Mixed & 152 & 133 & 130 & 415 \\
& Pine & 154 & 41 & 57 & 252 \\
\hline
\end{tabular}

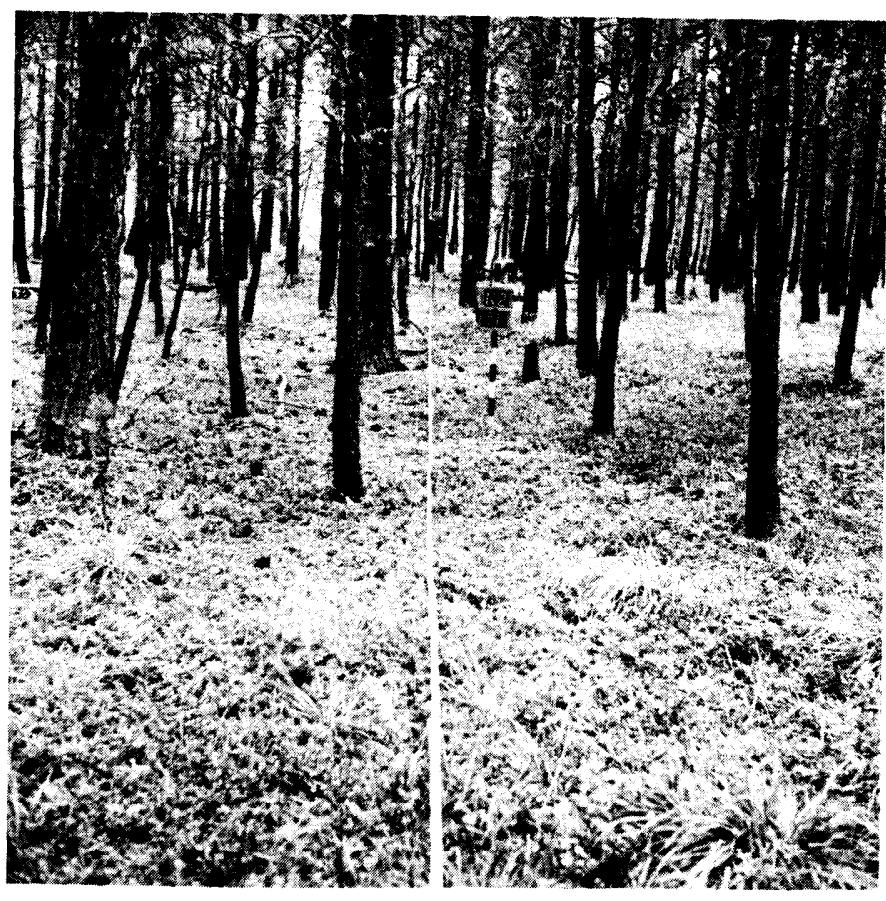

Fig. 2. Understory cover of most species was least in the pine communities. (U.S. Forest Service photo by Kieth E. Severson)

breast-height ( $\mathrm{dbh}$ ) for each overstory species was recorded.

Annual understory forage production in pounds per acre air-dried for shrubs, forbs, and grass was determined by clipping annual growth from ten, 9.6 square-foot plots, located at random in each belt transect.

Percent cover for understory species was estimated using 50 randomly selected 1.0 square-foot plots along the centerline of each belt transect. Cover estimates were made for each species with the exception of grasses and sedges which were treated as a group.

Use of aspen, pine, and mixed aspen-pine by deer and cattle was estimated using counts of deer pellet groups (Bennett et al., 1940) and cattle chips (Fuller, 1928) found on the nine belt transects.

\section{Results and Discussion}

\section{Overstory Basal Area}

Analysis of variance indicated a difference $(P<.01)$ in basal areas between aspen, mixed aspen-pine, and pine, and also between study areas A, B, and C. Mixed aspen-pine appeared visually as consisting of $50 \%$ aspen and $50 \%$ pine; however, the average basal area was 29.4 square feet per acre for aspen and 104.2 square feet per acre for pine (Table 1). Overstory basal area was least for the aspen community, intermediate for the mixed aspen-pine, and greatest for the pine community.

\section{Understory Composition}

Fifty-nine species of shrubs and forbs were found in the communities; 54 were in the aspen, 49 in mixed aspen-pine, and 39 in pine.

Cover for understory species was greatest in aspen, in termediate in mixed aspen-pine, and least in pine (Table 2). The cover of most species was greatest in the aspen stands (Fig. 1); bearberry, spirea, and juniper were notable exccptions with greater cover in the pine stands (Fig. 2).

Four preferred summer deer-food species (aster, serviceberry, vetchling, and American vetch) in the northern Black Hills (Schneeweis, 1969) generally decreased in abundance 


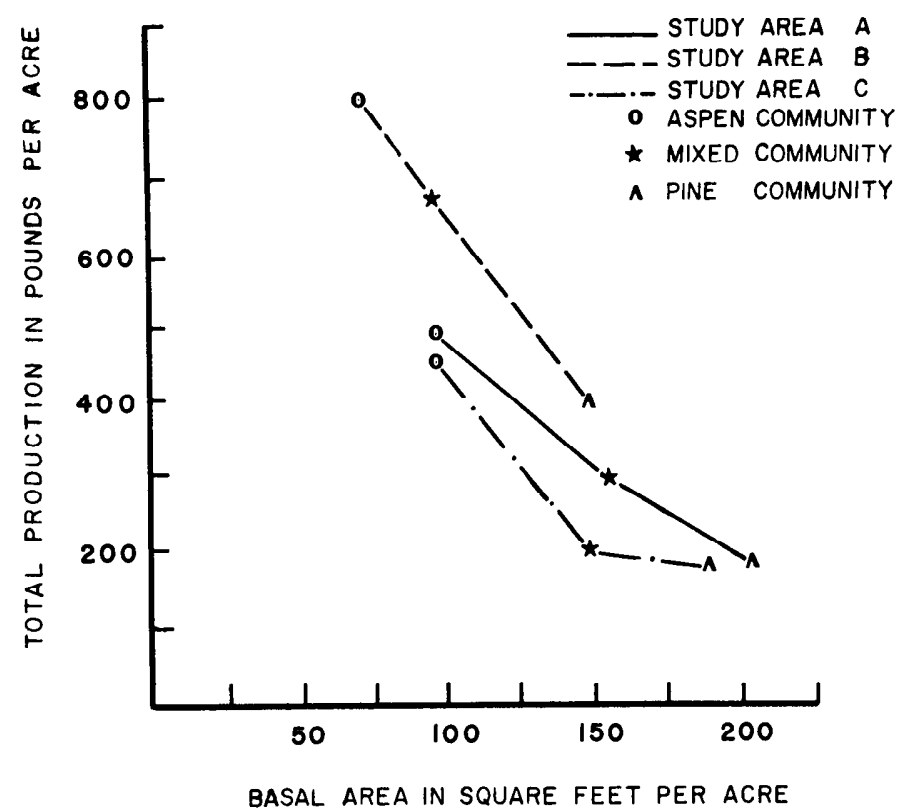

Fig. 3. Total understory production (air-dried forage) as related to overstory basal area.

from aspen to pine communities (Table 2). The relative abundance of these preferred species suggests that aspen stands should be primary feeding areas.

\section{Understory Production}

Total production was significantly different $(P<.01)$ between communities, with greatest production in aspen and least production in the pine communities (Table 3). Also, the proportion of the total production in shrubs, forbs, and grasses was significantly different $(P<.01)$ between communities. Generally, shrub production in the mixed aspen-pine understories did not change as much as forb and grass production. While shrub production was $25 \%$ less in the pine than aspen understories, forb and grass production was $80 \%$ and $69 \%$ less, respectively.

Differences in total understory production was no doubt influenced by different overstory basal areas; basal area of aspen overstories was least and that in pine was greatest (Fig. 3). Pase (1958), Pearson (1964), and Jameson (1967) each studied pine communities with variable basal areas and found that understory production was inversely related to overstory production.

\section{Deer and Cattle Use}

Counts of deer pellet groups and cattle chips made in 1969 and 1970 were used to estimate preference for the community types by deer and cattle.

Analysis of variance indicated more $(P<.01)$ use by deer of mixed aspen-pine than of other communities (Table 4). Aspen communities were used more $(P<.05)$ than pine communities. The high counts associated with mixed aspen-pine communities suggest that use by deer was not governed by single factors such as overstory type, overstory density, or understory production, but by a complex of habitat factors.

Number of cattle chips was different $(P<.05)$ between communities and was correlated $(P<.01)$ with understory grass production $(r=0.95)$. Other investigators have also shown a close relationship between grass production and cattle use (Julander, 1955; Reynolds, 1966).
Table 4. Number of deer pellet groups and cattle chips found on belt transects for aspen, pine, and mixed aspen-pine in three study areas, Black Hills, 1969-70.

\begin{tabular}{clcr}
\hline \hline $\begin{array}{c}\text { Study } \\
\text { area }\end{array}$ & Community & $\begin{array}{c}\text { Deer } \\
\text { pellet groups }\end{array}$ & $\begin{array}{c}\text { Cattle } \\
\text { chips }\end{array}$ \\
\hline A & Aspen & 50 & 9 \\
& Mixed & 60 & 11 \\
& Pine & 15 & 2 \\
B & Aspen & 26 & 22 \\
& Mixed & 39 & 5 \\
& Pine & 27 & 4 \\
C & Aspen & 30 & 53 \\
& Mixed & 53 & 50 \\
& Pine & 31 & 15 \\
Average & Aspen & 35 & 28 \\
& Mixed & 51 & 22 \\
& Pine & 24 & 7 \\
\hline
\end{tabular}

\section{Conclusions}

Among the aspen, mixed aspen-pine, and pine communities studied, aspen appeared to represent a subclimax species and ponderosa pine the climax species. Overstory basal areas were least in the aspen stands and greatest in the pine stands. Total understory production was greatest in the aspen communities and least in the pinc communities. Understory production was influenced by overstory basal area; however, other factors that we did not study may also influence understory production.

Deer preferred the mixed aspen-pine stands, followed by aspen, and pine. Preference was not governed by single habitat factors such as overstory type, overstory density, or understory production, but by an interrelationship of those factors. Cattle preferred the aspen communities, followed by mixed aspen-pine, and pine, with preference directly related to understory grass production.

\section{Literature Cited}

Baker, F. S. 1918. Aspen as a temporary forest type. J. Forest. 16:294-303.

Baker, F. S. 1925. Aspen in the central Rocky Mountain region. U.S. Dep. Agr. Bull. 1291.46 p.

Bennett, L. J., P. F. English, and R. McCain. 1940. A study of deer populations by use of pellet-group counts. J. Wildlife Manage. 4:398-403.

Fuller, J. M. 1928. Some physical and physiological activities of dairy cows. New Hampshire Agr. Exp. Sta. Tech. Bull. 35.29 p.

Jameson, D. A. 1967. The relationship of tree overstory and herbaceous understory vegetation. J. Range Manage. 20:247-249.

Julander, O. 1955. Deer and cattle range relations in Utah. Forest Sci. $1: 130-139$.

Pase, C. P. 1958. Herbage production and composition under immature ponderosa pine stands in the Black Hills. I. Range Manage. $11: 238-243$.

Pearson, H. A. 1964. Studies of forage digestibility under ponderosa pine stands. Proc. Soc. Amer. Foresters 71-73.

Radeke, R. E., and F. C. Westin. 1963. Gray wooded soils of the Black Hills of South Dakota. Soil Sci. Soc. Amer. Proc. 27:573-576.

Reynolds, H. G. 1966. Use of a ponderosa pine forest in Arizona by deer, elk, and cattle. Rocky Mt. Forest and Range Exp. Sta. Res. Note 63.7 p.

Schneeweis, J. C. 1969. A food habits study of whitetail deer in the northern Black Hills. M.S. Thesis. South Dakota State Univ., Brookings. 59 p.

U. S. Department of Agriculture and U. S. Department of the Interior. 1967. Black Hills area resources study, U. S. Dep. of Agr. and U. S. Dep. of the Int., Washington, D.C. 225 p. 